\title{
Japanese Foreign Policy towards the Republic of Croatia: Preventive Diplomacy and Post-conflict Reconstruction 1994 - 1997
}

\author{
Marcela Peric \\ Keio University, Graduate School of Law \\ marcela.peric01@gmail.com
}

\begin{abstract}
This article analyses the policy of the Japanese Ministry of Foreign Affairs (MOFA) towards the former republics of the Socialist Federal Republic of Yugoslavia (SFRY) in the 199os during the Yugoslav crisis. It argues that MOFA adopted an indirect foreign policy approach since it acted through the United Nations and the Organization for Security and Cooperation in Europe (OSCE) to help foster the peace process. The article particularly focuses on the roles played by Yasushi Akashi, the head of the United Nations Protection Force (UNPROFOR) and United Nations High Commissioner for Refugees (UNHCR) Sadako Ogata, through whom Japan provided aid during the humanitarian crisis. Japan exerted its preventive diplomacy to defuse tensions in the successor republics and to prevent the spread of the conflict to Macedonia and Albania. After the end of the conflict, Japan's policy towards the region focused on post-conflict reconstruction and supporting the transition to prepare for the European integration process.
\end{abstract}

Key words: Croatia, EU, Japan, post-conflict reconstruction, preventive diplomacy, SFRY, UN

\section{Introduction}

The international community was making efforts to define the new world order in the post-Cold War era after the fall of communism as an ideology. Developing countries and former communist countries had difficulties in the economic and social areas in their reform efforts while converting to democracy. Moreover, the democratic breakup of a number of multi-ethnic communist nation states into individual nation states was a result which had the potential to bring conflict. The conflict in the former Socialist Federal Republic of Yugoslavia (former SFRY) escalated into an international war between newly independent democracies in post-Cold War Europe. The war was rooted in ethnic, religious and historical factors. Such regional conflicts are starting to be considered not only as a domestic issue but also as a security threat to the post-Cold War international community since they have an enormous impact. The impact on the entire international community presents in the form of refugees, humanitarian problems and disruption of the international economy. Therefore, to contain or prevent conflicts, not only concerned countries but the international community as a whole needed to unite efforts to deal with such threats and render assistance. 1 
According to UN Secretary General Boutros-Ghali (1995), preventive diplomacy is action to prevent disputes from arising between parties, to prevent existing disputes from escalating into conflicts and to limit the spread of the latter when they occur. Postconflict reconstruction is a complex concept consisting of a unifying conceptual framework systemized by Jabareen (2013). The framework is composed of failed state conditions, exogenous intervention, sequencing, security, reconstruction which reduces conflict, multi-level actors, inclusive themes and holistic approach, and westernization of states. To apply Jabareen's post-conflict reconstruction concept (2013) to this article, it is argued that the political agenda of post-conflict reconstruction is to transform a "failed state", in this case former Yugoslav republics, into a "normal" western liberal state.

Previous research analyzed the influence of Western powers, European countries and the US on the Yugoslav crisis, and dealt with Japanese relations with Western European countries.2 Huliaras (2007) wrote about Japanese participation in South Eastern Europe, and Bechev (in Bacon, Mayer, \& Nakamura, 2015) explored the cooperation between the European Union (EU) and Japan in the Balkans regarding post-conflict nation-building. Both agree that economic considerations were more important in Japanese aid to the eastern Balkans, and political motivations, linked to Japan's efforts to become a permanent member of the Security Council, were more important in Japanese aid to the western Balkans (Huliaras, 2007, p. 27; Becher, 2015, p. 207). Glisic (2016, 2017) explored the relations between Japan and Yugoslavia during the Cold War. The aim of this article is to expand on previous research by investigating the development of relations between Japan and former Socialist Federal Republic of Yugoslavia (SFRY) in the post-Cold War period and determining the nature of Japanese foreign policy during the end of the Yugoslav crisis. Taking into account EU enlargement, with Slovenia and Croatia becoming first two EU members in

${ }_{2}$ For relations of Japan with the Europan Union see: Bacon, P., \& Mayer, H., \& Nakamura, H. (2015) The European Union and Japan: A New Chapter in Civilian Power Cooperation? England: Ashgate Publishing Limited. Gilson, Julie (2000) Japan and the European Union: A Partnership for the Twenty-First Century?, Macmillan Press Ltd. Glen D. Hook (2011) Japan's International Relations: Third Edition, The University of Sheffield. Mykal, Olena (2011) The EU-Japan Security Dialogue: Invisible but Comprehensive, Amsterdam University Press, Amsterdam. Michito, Tsuruoka (2008) 'Expectations Deficit' in EU-Japan Relations: Why the Relationship Cannot Flourish, in: Current Politics and Economics of Asia, Volume 17, Issue 1, 107-126., Michito, Tsuruoka (2012) The Development of Political and Security Relations between Japan and Europe after World War II, Ph.D. diss., Department of War Studies, King's College London. Hosoya, Yuichi (2012) The evolution of the EU-Japan relationship: towards a 'normative partnership'?, Japan Forum, 24:3, 317-337.

Relations of Croatia, the Central and Eastern Europe and European Union are analyzed in: Grubiša, D., \& Beširević, N., Špehar, H. (2012) Politički sustav Europske Unije i europeizacija hrvatske politike (Political System of the European Union and Europeanization of Croatian politics), Fakultet političkih znanosti, Zagreb. Glaurdić, Josip (2011) The Hour of Europe: Western Powers and the Breakup of Yugoslavia, Yale University. Smith, Karen E. (2004) The Making of EU Foreign Policy: The Case of Eastern Europe, Palgrave Macmillan. Beširević, Nataša (2013) Vanjska politika Europske Unije i Zapadni Balkan (Foreign Policy of the European Union and Western Balkans), Fakultet političkih znanosti, Zagreb. Blockmans, Steven (2007) Though Love: The European Union's Relations with the Western Balkans, T.M.C. Asser Press, The Hague.

Critique of United Nations peacekeeping in Croatia can be found in: Miškulin, Ivica (2010) Icecream and Sun - The European Community Monitoring Mission and Croatia, 1991-1995, Casopis za suvremenu povijest (Journal of Contemporary History). Miškulin, Ivica (2011) An Avoidable Failure: Peacekeeping in Croatia, 1991-1995, Review of Croatian History 7/2011, No.1, 37-77.

See also: Gilson, Julie (2000) Japan in Kosovo: lessons in the politics of 'complex engagement', Japan Forum, 12:1, 65-75. Michito, Tsuruoka (2013) NATO and Japan as Multifaceted Partners, NATO Defense College, Research Division, No. 91, Rome. 
Western Balkans, Japan-EU relations regarding shared interests in former SFRY are illuminated.

This article combines resources on diplomatic history, contemporary history and foreign policy. Firstly, the article uses available historical materials as primary sources from Japan and Croatia. They include disclosed documents from Japanese Ministry of Foreign Affairs (MOFA), Diplomatic Bluebook and Tuđman's Archive. Secondly, primary sources also consist of interviews with Japanese and Croatian diplomats. Thirdly, secondary sources include published works of Japanese diplomats and officials, such as Hisashi Owada, and the policy magazine Gaiko Forum.

Considering the military contribution of the United States, which acted as a "hard power" in the military sphere, the question which was not dealt with in previous research $_{3}$ is the contribution to the conflict resolution in the former Yugoslavia made by pacifist Japan, as the "soft power" and "smart power" in the civilian sphere. Therefore, this article explores the role of Japan during the end of the war in the former SFRY from 1994 to 1997 in the civilian sphere. Japan as a United States (US) ally and world leader during the 1990s in providing Official Development Assistance (ODA), led proactive contribution policy towards former SFRY countries to contribute to conflict resolution. Due to its Peace Constitution and Article 9, Japan could not send Self Defense Forces (SDF) to engage in peace missions during conflict. However, with its Peace Cooperation Law from August 1992, Japan managed to participate in United Nations Peacekeeping Operations (UN PKO) missions in Angola, Cambodia, Mozambique and El Salvador. Since the war in the former SFRY was still hot and many peace plans failed, it was too dangerous to send SDF to UN PKO in the former SFRY. Nevertheless, Japan managed to contribute proactively with its indirect foreign policy approach. This indirect foreign policy was exercised in the civilian sphere, through means of diplomacy, bilateral relations, contributions through multilateral fora such as UN, OSCE and G7, and through providing humanitarian and reconstruction aid.

Japan wanted to play a proactive role in the international order, often engaging in UN endeavours or in the name of the UN itself. Examples are settling regional conflicts (UN PKO in Mozambique and El Salvador), humanitarian contributions in refugee aid (Rwanda), reconstruction development (Middle East, Cambodia, El Salvador), ultimate abolishment of weapons of mass destruction and demilitarization (UN General Assembly adopted Japan's proposal), expansion of ODA as a proactive support to every world region in democratic movements with economic and social efforts. In the former SFRY, Japan worked on conflict containment through UN institutions and through post-conflict reconstruction and development. Japan also contributed its human capital, with high-profile Japanese officials working for international organizations. Most prominent was Mr. Akashi Yasushi who was appointed in 1994 as Special Representative of the UN Secretary-General to Zagreb. The United Nations Protection Force (UNPROFOR) was spread out through Bosnia, Croatia and Macedonia to protect human rights, support cease-fire and prevent further conflict. Another prominent Japanese working during the 1990s in the former SFRY was United Nations High Commissioner for Refugees (UNHCR), Ms Sadako Ogata. Japan made financial contributions to humanitarian and rescue aid through until March 1996 to the former SFRY. In total, 2.4 billion dollars aid was distributed through UNHCR, the 
World Food Programme (WFP), the International Organization for Migration (IOM), the United Nations Volunteers (UNV) programme, the International Committee for the Red Cross (ICRC), the United Nations Industrial Development Organization (UNIDO), the World Health Organization (WHO), the United Nations International Children's Emergency Fund (UNICEF), UNPROFOR and the Office of the United Nations High Commissioner for Human Rights (UNHCHR). 4 That is why Japan's indirect approach is emphasized through the large amounts of financial aid contributed through a broad range of UN aid organizations. For example, this indirect approach was part of preventative diplomacy in Macedonia and Albania aiming to contain the conflict in Bosnia from spilling-over5.

This article focuses on the Japanese foreign policy in Croatia because it was in Croatia that the focal point of conflict grew into an international war after Slovenia and Croatia had been recognized internationally as independent republics. Pursuing rapprochement with Western Europe, these two republics became UN member states and subsequently the first members of the EU and NATO in the region. Therefore, since Japan shares liberal values with the West, relations with Slovenia and Croatia developed rapidly. Croatia's capital Zagreb became the place for the UNPROFOR Headquarters, also managing the Bosnian peace process after conflict spill-over. Since Japan promoted non-military cooperation with the UN, the article argues that its primary focus was on relations with Croatia. For Croatia, military cooperation with the US was of utmost importance due to the rigidity of the UN mandate because UNPROFOR was not allowed to enforce peace, analysed in the third section. This leads to the disregarded reverse of the military-civilian coin: civilian cooperation with the EU and Japan as main actors. During the war, it was often neglected to acknowledge the role of other states, actors and international organizations who supported the lives of civilians. Therefore, this article limits its focus on less researched non-military contributions by Japan. Due to its scope, the article does not investigate the Japanese foreign policy in all other former SFRY republics. Therefore, this article sheds new light on the area of EU civilian cooperation with Japan in Croatia which was indispensable for conflict containment through preventive diplomacy and post-conflict reconstruction.

\section{Japanese foreign policy in the post-Cold War period}

\section{Continuation of US-EU-Japan Trilateralism}

In the aftermath of the Second World War, the economic and security cornerstone of Japan's foreign policy has been closely linked to its relations with the US. Japan's responsibilities to the US and the international community rose due to Japan's increase in postwar prosperity under the international order sustained by free world countries and led by the US (Gaikoseisho, 1989). Additionally, Western European nations, specifically those of the European Community (EC), would have greater international roles and responsibilities, since they began to create the Single Market. They are key factors for political cooperation regarding the rebuilding of East-West relations. Therefore, Japan placed more importance on the construction of a closer relationship with Europe in the 1990s. 
Japan used the concept of trilateralism to advance relations with Europe. According to Owada (1995), the concept of trilateralism describes the international relations between North America, Western Europe and Japan as members of the Western bloc, which developed during the Cold War. In the 1970s, the US strongly supported trilateralism because of tensions between advanced countries and the widening gap between powerful regions, due to political, economic, and other problems the world was facing on an international level. Japan supported trilateralism due to concern for its future, encircled by communist threats from Asia. The era of rapid economic development brought Japan wealth, but also social distortions and trade conflicts with the US and Europe. Since the relations between Europe and Japan were the weakest in this triangle, trilateralism provided an opportunity for Japan to rebuild and facilitate relations with Western Europe. Also, it signalled Japanese equality with the US and Europe in both political and economic spheres. Owada claimed that attaining a real balance in these trilateral relations would become a cornerstone for stronger relations between Japan and the Western Alliance. Therefore, stronger and more balanced cooperation among Japan, the US and Europe was becoming more and more essential. Hosoya (2012) argues that Cold War trilateralism translated into a post-Cold War 'normative partnership,' since both Japan and the EC advocated international law and multilateralism. This research shows that trilateral actors took a synchronized approach towards newly democratized countries in Europe, including the Socialist Federal Republic of Yugoslavia (SFRY). Therefore, trilateralism, together with bilateral and multilateral cooperation in international fora, explains the unified position of Japan with the US and Europe. This means that a turbulent transition to democracy in the Soviet Union and Eastern Europe concerned Japan as much as the US and Western Europe.

\section{Multilateral Engagements}

During the Cold War, Japan's diplomacy was characterized solely as a "member of the Western bloc", but in the 9os it was expected that Japan would uphold that role and play a major role in building a new framework for international cooperation with every country which shares the same values. Firstly, to foster global as well as regional cooperation in the Asia-Pacific region. Secondly, to contribute to building a peaceful and prosperous world. In 1995 Japan became chair of the Asia Pacific Economic Cooperation (APEC). In order to realize its position in the world order, it was important for Japan to advance mutual trust with other nations. This is indispensable for the fulfilment of Japan's responsibilities in the international community. Because of Japan's Second World War legacy, it was necessary to regain the trust of the international community as a country striving for pacifism and anti-militarism. To realize this, on the 50th anniversary of the Second World War on 15 August 1995, Prime Minister Tomiichi Maruyama issued a statement to express Japan's remorse over the past. It was declared that Japan's future path should be to make every effort to build world peace in line with its no-war commitment: "Building from our deep remorse on this occasion of the 50th anniversary of the end of the war, Japan must eliminate selfrighteous nationalism, promote international coordination as a responsible member of the international community and, thereby, advance the principles of peace and democracy. At the same time, as the only country to have experienced the devastation of atomic bombing, Japan, with a view to the ultimate elimination of nuclear weapons, must actively strive to further global disarmament in areas such as the strengthening of the nuclear non-proliferation regime. It is my conviction that in this way alone can 
Japan atone for its past and lay to rest the spirits of those who perished." 6 Japan has high regard for respect of basic human rights, democracy and pacifism as ideals included in its Constitution. To realize these ideals the international community needs to cooperate since interdependence is rapidly deepening in a globalizing world. Therefore, responsibility for its role in the international community is the foundation of Japan's state interest.

According to Iokibe (2011), Japanese diplomacy faced several challenges in the postCold War period. Firstly, the Japan-US alliance needed to be redefined, strengthened and expanded to deal with new challenges and threats. Secondly, Japan needed to actively participate in multilateral frameworks regionally and internationally. The third challenge was related to security matters; Japan was expected to greatly expand its international role and international contributions, such as in the UN fora. Lastly, Japanese diplomacy needed to become more proactive, especially regarding its relationship with the US. Later in 1998, this could be observed in Obuchi's concept of "human security" and the initiative to ban landmines (Iokibe, 2011). Therefore, Japan engaged in a multilateral regional (Conference for Security and Co-operation in Europe - CSCE, later OSCE and EU) and global (UN) framework to help resolve the Yugoslav crisis. Japan expanded its international role regarding security matters by engaging first with Cambodia, and then with the former Yugoslavia through the UN. This shows the expansion of the Japanese foreign policy horizon towards Europe after the Cold War. Since Japan emerged as an economic power comparable to the US, it was expected to play a larger role globally and not to focus only on Asia.

Major challenges facing the international community remained unresolved: economic recovery of the former Eastern bloc; international conflict in former Yugoslavia; the proliferation of weapons of mass destruction and missiles; the suspected development of nuclear weapons in North Korea and various difficulties in the countries of the former Soviet Union. A new approach was necessary; the framework of Japan-EuropeUS trilateral cooperation and regional institutions needed to be explored further, especially through partnerships with former Eastern bloc and developing countries. To that effect, in April 1993, the G7 Russia summit was held in Tokyo, where it created an international framework for assistance coordination and compiled a package of specific measures. The G7 Russia summit also reaffirmed a united position in the UN and the commitment to diplomatic resolution of the conflict in Croatia, and Bosnia and Herzegovina.

\section{Japan's Indirect Approach to Croatia: G7 and UN}

Japan did not want to risk the future of its market in the region by siding with any nation of the former SFRY.7 For Japan, further spread of conflict and a humanitarian crisis was of the utmost concern. By 1995, Japan provided 12 million dollars in humanitarian aid and economic assistance as preventive diplomacy for possible spillover of tensions to Macedonia and Albania, and later to Hungary.8

6 MOFA. (2018, October 28). Statement by Prime Minister Tomiichi Murayama "On the occasion of the 50th anniversary of the war's end". Retrieved from https://www.mofa.go.jp/announce/press/pm/murayama/9508.html.

7 Interview with Serbian Ambassador to Japan Mr. Nenad Glišić, 27 February 2019, Tokyo.

8 Gaikoseisho (January 1 - December 31, 1995, 1995). Tokyo: Gaimusho. 
Croatia and Japan have been indirectly connected through multilateral international organizations, especially the UN. Japan had indirect insight into a situation in the former SFRY through its nationals working as UN officials. Japanese UN officials were able to use their position to ask MOFA for more aid and humanitarian assistance. Since Slovenia and Croatia had already become UN members, they were more politically receptive of cooperation than other former republics. Moreover, New Yugoslavia (Serbia and Montenegro, FRY) was under UN sanctions.

On 4 January 1994 Mr. Yasushi Akashi was appointed as Special Representative of the Secretary-General for UNPROFOR, after a successful UN PKO mission in Cambodia, and led the mission from the regional headquarters in Zagreb. The mission included military and civil affairs (including civilian police), public information and administrative components. 9 Japan made contributions towards reaching a peace settlement in the former Yugoslavia with financial help, personnel and with its proactive diplomatic efforts of officials in the framework of the UN.10

Croatian President Franjo Tuđman remained faithful to the principles of the UN Charter and was willing to prolong the UNPROFOR mandate. However, some problems remained - UNPROFOR did not fulfil its most essential task, full implementation of all relevant Security Council resolutions. This was the cause of Croatian government's trust decline in UNPROFOR.

Therefore, President Tuđman maintained contact with state leaders he considered crucial for the success of Croatian foreign policy, future membership in the NATO and EU. The so-called Contact Group (CG) consisted of the US President William Clinton, the President of the Russian Federation, Boris Yeltsin, German Chancellor Helmut Kohl, President of the Republic of France, Francois Mitterand and Prime Minister of the United Kingdom, John Major. On 27 July 1994 Preident Tuđman wrote to the Contact Group in order to make them realize that this was the time to show strength and determination in applying decisions made by the Security Council and the most important actors of international community. He informed them that the Serbs were stalling negotiations hoping that with time they would achieve legalization of their achievements gained through aggression. The President emphasized the fact that the international community clearly showed that the United Nations Protected Area (UNPA) were occupied parts of Croatia and stated that Croatia would never give them up.11 The G7 in Naples confirmed the Contact Group peace plan, with a 'carrot and stick' sanctions approach which was partly successful - FRY broke off relations with Bosnian Serbs on 19 July to get sanctions lifted as the international isolation had led to a grave economic situation. However, Bosnian Serbs continued to reject the peace plan since they occupied 70 per cent of the Bosnian territory. Drastic measures such as a weapons embargo on Muslims and air raids on Serbs were considered.12

The acts of hostilities did not cease - acts of aggression on Dubrovnik and attacks on Bosnia and Herzegovina by rebel Serbs from UNPA in Croatia, areas which UNPROFOR needed to protect. Therefore, President Tuđman wrote to the President of the UN Security Council, Ms Madeleine Albright, that the Republic of Croatia

\footnotetext{
9 Daniel Bethlehem and Marc Weller, ed. (1997) The Yugoslav Crisis in International Law, Part of Cambridge International Documents Series, Cambridge University Press.

${ }_{10}$ Cambodia, Somalia and SFRY received each \$200,00o,ooo aid from Japan. Foreign Policy Speech by Foreign Minister Watanabe to the 126th Session of the National Diet, January 22, 1993.

11 \#055/94. Tuđman's archive.

${ }_{12}$ Gaikoseisho (January 1 - December 31, 1995, 1995). Tokyo: Gaimusho.
} 
"urgently requests assistance from the UN in ending these attacks. Specifically, the Government of Croatia requests air strikes on the attacking forces." 13 However, the UN did not have sufficient military resources to address the situation. That is why the UN for the first time in its history coodinated its efforts with the North Atlantic Treaty Organization (NATO) for operational support. General Secretary Boutros-Ghali wrote that the most developed example of operational support to the UN was NATO's provision of air power for UNPROFOR. The UN provided techical advice to NATO which handled operation on its own.14 President Tuđman approved NATO air strikes against targets in the UNPA that were being used for attacks on Bosnia and Herzegovina from Croatian soil by rebel Serbs. Approval of NATO's proposal for Close Air Support for UNPROFOR was granted for the duration of one week, starting from 2000 GNT on 18 November 1994. The President also stated that Croatia was prepared to negotiate with NATO for Close Air Support on a longer-term basis.15 The President was satisfied with the effective action of NATO Air Force on 21 November 1994 in the occupied part of Croatia, undertaken upon request of the Special Representative $\mathrm{Mr}$ Akashi and Commander of UNPROFOR, and he encouraged UNPROFOR to take control of those borders of Croatia and Bosnia and Herzegovina which aligned with the UNPA. The Republic of Croatia approved in principle the extension of the NATO Close Air Support "under condition that the operations are conducted in full respect of the sovereign rights of Croatia and in full coordination with Croatian authorities." 16 In 1995, the conflict got worse. NATO continued aerial bombardment to destroy Bosnian Serb's footholds and liberate the UN PKO members held as hostages. The international community finally agreed that stronger actions, including military ones, were necessary to contain Serbian military power.17

However, at the beginning of 1995, according to letter from President Tuđman to Secretary-General Boutros-Ghali, the Croatian government was seriously considering breaking off cooperation with the UN.18 Although the UN Security Council confirmed Croatian sovereignty over the disputed UNPA, UNPROFOR was not willing to use force to achieve this goal, upholding the principle of solving conflict through negotiations. Upholding the status quo benefited the Serbian occupiers, thus UNPROFOR was blocking NATO and Croatia to return lost territory.

President Tuđman wrote to Secretary-General Boutros-Ghali about how the lack of progress in resolving the Yugoslav crisis disrupted international peace and paralyzed numerous international fora. He acknowledged the initial positive effects of the Vance Plan and the UNPROFOR mission and that, together with UNHCR, Ms. Sadako Ogata and other humanitarian organizations had made significant contributions regarding humanitarian needs. However, despite UNPROFOR's endeavours, none of the provisions from various Resolutions had been implemented, and neither had the control of the Croatian border which was critical for the peace process. The President concluded that "although UNPROFOR has played an important role in stopping violence and major conflicts in Croatia, it is an indisputable fact that the present character of the UNPROFOR mission does not provide conditions necessary for establishing lasting peace and order in the Republic of Croatia, a sovereign UN

\footnotetext{
13 \#072/94. Tuđman's archive.

14 Boutros Boutros-Ghali (1995) An Agenda for Peace, United Nations, New York.

15 \#073/94. Tuđman's archive.

16 \#074/94. Tuđman's archive.

${ }_{17}$ Gaikoseisho (January 1 - December 31, 1996, 1996). Tokyo: Gaimusho.

18 \# 006/95. Tuđman's archive.
} 
Member State." 19 The President discussed all questions regarding withdrawal with Special Representative Mr. Akashi and permitted further operations of the Headquarters, responsible for continuing support to operations in Bosnia and Herzegovina. Lastly, it was emphasized that Croatia would stay fully commited to the interests of the international community focused on the peaceful establishment of a new international order in the region.20

In order for the UN to replace UNPROFOR and reverse the failures and loss of trust, the United Nations Confidence Restoration Operation (UNCRO) was established on 31 March 1995.21 On 30 July 1995, Special Representative Mr Akashi and General Bernard Janvier met with Serbian rebels in the town of Knin, where the conflict had originated. Mr. Akashi wrote a note to President Tuđman about this meeting. Mr. Akashi's negotiation efforts ensured a cease-fire and further negotiations, but failed to recognize that the Serbian claim over territorial authority was gained through an occupation. This is why President Tuđman did not welcome the result of negotiation since Mr. Akashi did not mention UNCRO who had a mandate in Croatia, but only Knin leadership and the Republic of Serbian Krajina (RSK), which equated to an acknowledgment of Serbian leadership, and denial of Croatian sovereignty over the disputed territory.

According to Tsukimura (2006), the international community did not recognize the pseudostate the Republic of Serbian Krajina, but allowing Bosnian Serbs to participate equally in negotiations was a partial acknowledgement of recognition. 22 This negotiation attempt of Mr. Akashi can be interpreted as an attempt to stop conflict at its origin place, and improve the humanitarian situation while upholding UN neutrality principles. In the post-Cold War period, the UN started to deal with non-state actors, making these negotiations possible.23

The end of the so-called crisis in former Yugoslavia was not resolved until the Croatian Army decided to free its occupied territories with the help of NATO's intervention. In the civilian sphere, the EU achieved positive effects through the usage of all available instruments of conditionality and implementation of international law. However, the negative effects outstripped the positive ones: such as the problematic implementation of sanctions, the mismatch between events and realization of their importance, inadequacy of international legislation, various national interests, the decision to implement force in the UN framework, and the clash of interests among political partners. 24 In this civilian sphere, Japan could contribute with diplomatic and monitoring personnel only through the UN and OSCE, and was indecisive when it came to taking a more firm stance on political decisions, always taking into account the position of the US and UN.

Croatian military operations were victorious and brought the Knin area back under control. This changed power relations in the region and made Bosnian Serbs ready to

\footnotetext{
19 Ibid.

20 Ibid.

${ }_{21}$ UNCRO consisted of 6,581 troops, 194 military observers and 296 civilian police. Mandate was terminated on 15 January 1996. United Nations.

${ }_{22}$ Tsukimura, T. (2006) Ethnopolitical Leaders in Internal Wars in Croatia, and Bosnia and Herzegovina, Japan: University of Tokyo Press.

${ }_{2}$ Akashi, Y., Okamoto, Y. (1998, June, No. 119.) Gurobarizeshon wa Nihonjin no PKO Ishiki ni mo, Gaiko Forum, pp. 82-87.

${ }_{24}$ Beširević, Nataša (2013) Vanjska politika Europske Unije i Zapadni Balkan (Foreign Policy of the European Union and Western Balkans), Fakultet političkih znanosti, Zagreb, pg. 259-261.
} 
compromise. After the achievement of the Dayton Peace Agreement, war in Croatia officialy ended with signing of the Erdut Agreement on 12 November 1995, peaceful reintegration of east Slavonia with the rest of Croatian territory and normalization of political relations with Serbia and Montenegro. 25

According to Tsukimura (2006) the main reason why the Dayton peace negotiations succeeded while previous peace conferences failed, was because in Dayton for the first time Presidents Tuđman, Milošević and Izetbegović gathered as leaders of respective nations - Tuđman as leader of all Croats, Milošević as a leader of all Serbs and Izetbegovic as a leader of all Muslims, overseen by the US. The international community had to accept these leaders as respresentatives of their peoples, not their countries. It means that in the former SFRY peoples were in war, not republics.26

\section{Role of Japan in Peace Implementation and Reconstruction}

Japan's position regarding the peace process in the former Yugoslavia was that ethnic conflict was essentially a European problem, but from humanitarian standpoint and from the standpoint of creating a new international order after the Cold War, it had global implications. Therefore, Japan wanted to be engaged in peace implementation and reconstruction processes, so it could assume its role in the world, commensurate with its economic power. On 8 March 1995, the EU Commission sent the communication "Europe and Japan: The Next Steps" to the Council. After The Hague declaration, the Next Steps defined more specifically the areas of cooperation. The EU actively supported and wanted to participate in Japan's greater political involvement in global foreign and security policy (Keck, 2013: p. 120). The EU encouraged Japanese involvement in the Yugoslav crisis, while after Japanese lobbying it was agreed that the EU will join the Korean Peninsula Energy Development Cooperation (KEDO) (Keck, 2013: p. 122). Therefore, for Japan engagement in Yugoslav crisis was beneficial for its foreign policy and for improving cooperation with the EU. Vice versa, an engagement by the EU in the Asia could be anticipated.

After the Dayton Agreement, a peace implementation phase followed in Croatia and Bosnia and Herzegovina. An international military and civilian support system were provided to the parties who secured peace implementation. Instead of UNPROFOR, UNCRO took over and an additional 60 o00 NATO IFOR forces which were deployed to secure compliance with the Dayton Agreement. Regarding public welfare, humanitarian and civil aid, political means to hold elections, reconstruction and mechanisms for adjusting aid measures were agreed upon. 27 Securing permanent peace and the implementation of the Dayton Agreement by all parties was the next task for the international community, and therefore for Japan as well. The MOFA recognized the peacebuilding in former Yugoslavia as international task for building a post-Cold War order in Europe.28 Therefore, Japan acted as an active member of the

\footnotetext{
${ }_{25}$ Miroslav Tuđman ed. (2015) Tuđmanov arhiv (Tuđman's archive), Hrvatska sveučilišna naklada, Hrvatski institut za povijest, Book IV „Godine pobjede: 1994. i 1995. (The Years of Victory: 1994 and 1995)“, Ante Nazor: Pregled djelovanja hrvatskih snaga u Hrvatskoj i Bosni i Hercegovini 1990-ih (An Overview of the Actions of Croatian Military Forces in Croatia and Bosnia and Herzegovina).

${ }_{26}$ Tsukimura, T. (2006) Ethnopolitical Leaders in Internal Wars in Croatia, and Bosnia and Herzegovina, Japan: University of Tokyo Press.

${ }_{27}$ Gaikoseisho (January 1 - December 31, 1996, 1996). Tokyo: Gaimusho.

28 Gaikoseisho (January 1 - December 31, 1996, 1996). Tokyo: Gaimusho.
} 
Peace Implementation Council (PIC) in the civilian sphere. Japanese efforts after Croatia extended to other former SFRY republics, especially Bosnia and Herzegovina.29

Chart below is adopted from MOFA Diplomatic Bluebook and it clearly divides civilian cooperation and military cooperation, as well as high-politics diplomatic activities and the activities on site. Japanese peace implementation mechanisms in Bosnia are very similar to those in Croatia: diplomatic activity in PIC, comunication with UN High Representative Carl Bildt and taking role in Steering Committee where Japan directly involved with EU and G7 plus Russia. Japanese actions in civilian sphere are the main reason why the role of Japan in peace implementation processes in former SFRY is disregarded.

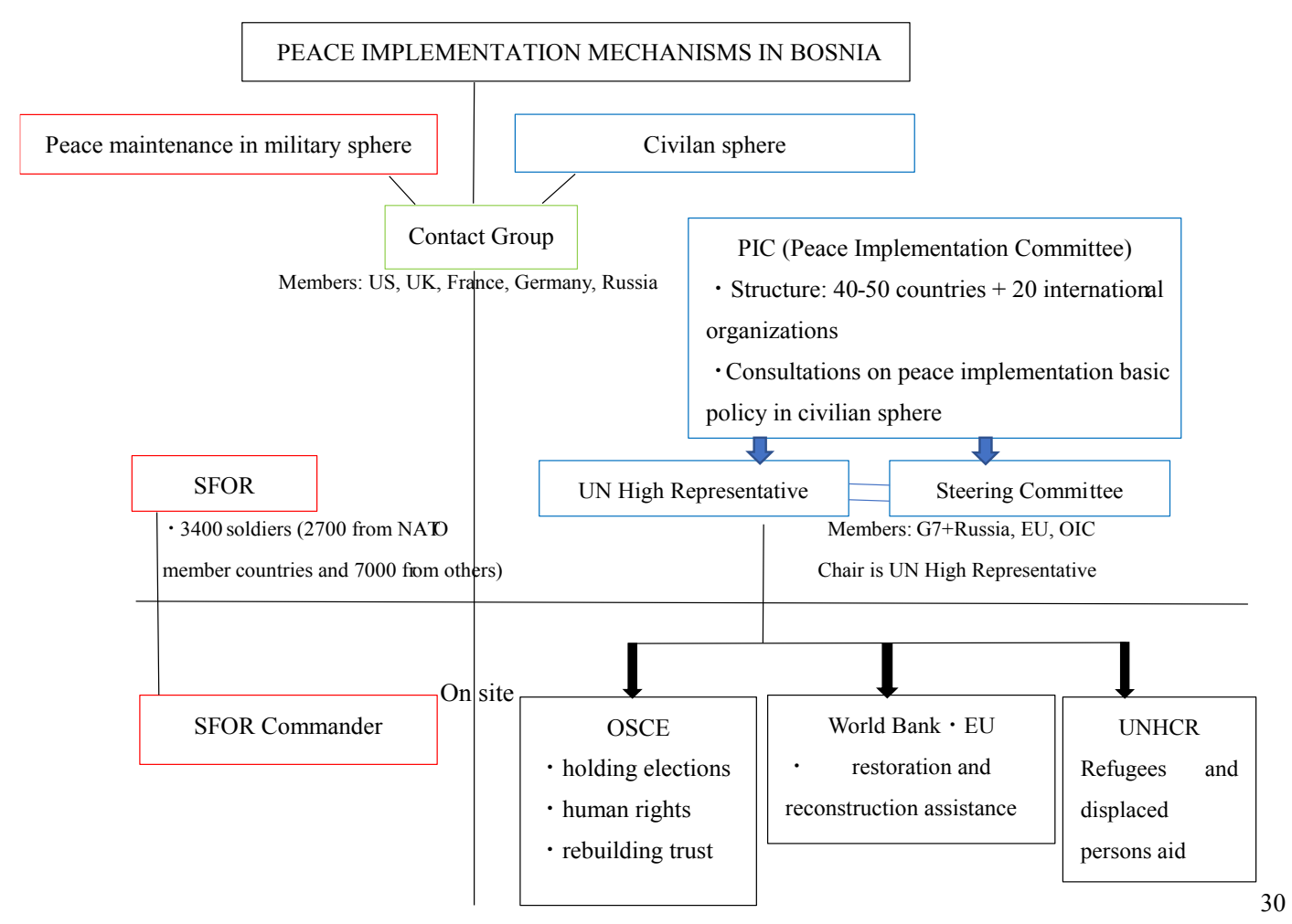

According to Croatian Ambassador in Japan, Mr. Dražen Hrastić, Japanese humanitarian aid was even greater in Bosnia and Hercegovina than in Croatia. Japanese International Cooperation Agency (JICA) was active in the region in all republics of former SFRY. Once Croatia and Slovenia fulfiled the Copenhagen criteria for joining EU, JICA's aid was replaced with EU programs. Still, even today JICA is an active developmental internatonal actor in remaining republics. 31

Japan used civilian tools in its foreign policy towards former SFRY republics during and after the war. As a measure of conflict preventive diplomacy for surrounding countries, Japan contributed 180 million dollars for humanitarian and refugee aid until 1996. In a diplomatic capacity Foreign Minister Yohei Kono visited Croatia and Hungary from 28 April to 2 May 1995 to talk with the parties in conflict and in that way participated actively in ensuring a peaceful resolution to the conflict. During his visit

${ }_{29}$ Gaikoseisho (January 1 - December 31, 1998, 1998). Tokyo: Gaimusho.

3o Gaikoseisho (January 1 - December 31, 1998, 1998). Tokyo: Gaimusho. Translated from Japanese.

31 Hrastić, Dražen. „Relations between Republic of Croatia and Japan.” Interview with Marcela Perić. Embassy

of Republic of Croatia in Japan: February 28, 2019. 
to Croatia expectations from Japan regarding economic recovery rose. Foreign Minister Kono also participated in a London conference where Japan took part in the steering committee related to peace initiative implementation in the newly formed civilian sector. 32

The most "visible face of aid" was a collaboration project between the UNHCR and the Japanese government for building a refugee shelter in Croatia near the city of Sisak. This project was promoted by Foreign Minister Kono during his visit to Croatia. Japan wanted to continue its efforts in peacebuilding even after the war. This project makes visible the cooperation of MOFA officials who were sent as monitors to the former SFRY and who drafted the plan for a refugee center with UNHCR staff members. Construction fee, management fee and all expenses were covered by Japanese donations to UNHCR. Two of the UNHCR members who led the refugee center project were Japanese nationals. They also managed to get support from other Japanese nationals living in Zagreb who formed an NGO and went to the center to help with origami, knitting, ikebana and choir workshops to help rehabilitate refugees. The shelter had Croatian, Serbian and Muslim refugees which made it challenging to run. The purpose of the shelter for Japan was not only to contribute in resolving problems between Yugoslav nations, but also on a grass-roots level to contribute to mutual understanding between each nation and Japan. This project was considered to be a necessary pillar of international contribution regarding humanitarian aid for refugees. It materialised Japanese diplomacy goals and became one of the symbols of Japan's humanitarian aid.33

After the Dayton Agreement, Japan started to normalise relations with all republics of the former Yugoslavia. With restarting trade, impoverished economies turned to improvement. Japan still did not recognized FRY (Serbia and Montenegro), due to concern with a status problem in the UN and condemnation as an aggressor in the international community. However, as sanctions were lifted, civilian economic missions were exchanged. Therefore, rapprochement was mainly in the economic sphere. However, Japanese business circles took more interest in Slovenia and Croatia, favoured by the international community, after private economic visits in July. In December 1996, exchanges of the Japan Croatia Parliamentary Friendship Alliance started. Croatian Vice President Granić visited Japan and exchanged views with Representative House Head Ito, Foreign Minister Ikeda and Transportation Minister Sato. Strong requests for opening a Japanese Embassy in Zagreb and supply of ODA were made.

Japan played a role in election monitoring in Bosnia. In order to implement peace and establish state institutions, the Peace Implementing Committee (PIC) attended by Japanese Foreign Minister Takamura, agreed to hold elections in Bosnia by the summer of 1997. NATO's deterrence force IFOR was replaced with a Stabilisation Force in Bosnia and Herzegovina (SFOR). Remaining tasks for the international community were the safe return of refugees, promotion of resettlement, securing freedom of movement, carrying out municipal elections and other peace implementation processes in the civilian sector. In January 1997 Japan recognized Bosnia and Herzegovina and a month later diplomatic relations were established. In July Foreign Minister Ikeda visited Sarajevo and diverse personnel and financial aid

${ }_{32}$ Gaikoseisho (January 1 - December 31, 1996, 1996). Tokyo: Gaimusho.

33 Matsumoto Hiroshi (March 1997, No. 103) Kuroachia Nanmin Sheruta Kensetsu, Gaiko Forum, pp. 58-59. 
were provided, such as election monitoring with 29 members in the OSCE framework, 130 million dollars for reconstruction and 87 million dollars for humanitarian aid.34

In 1997, the PIC concluded that peace implementation in Bosnia in the civilian sector was slower than expected, since the concerned parties did not fully adopt implementation measures. It was decided that if implementation did not suffice, the High Representative's authority would be strengthened, and he would be able to decide on measures if the parties themselves could not reach agreement. It was clear that the international community became more decisive acting as a protector of human rights. Furthermore, positive development was that postponed municipal elections went peacefully, mirroring national distribution. There was a fear of incidents, since those forms of elections had caused an outbreak of conflict and ethnic cleansing. This is why holding legitimate elections that would secure stability was indispensable in Bosnia.

The Keidanren mission visited Slovenia in October 1998 and views on strengthening economic relations were exchanged. To promote technical cooperation, experts from Japan were dispatched for the long term. The promotion of Japanese language and education was planned at Ljubljana University. In Croatia, Japan also started providing ODA for technical and cultural cooperation. In February 1998 the Japanese Embassy was established in Zagreb. In order to ensure stability in Macedonia, Japan provided interest-free loans, repaid public debt of 530 million yen and, through JICA, engaged in technical cooperation.35 The aid and loans were supplied through civilian groups such as Keidanren, bilateral and multilateral agencies such as ODA, JICA and UNHCR. Japan's main stabilisation measure was economic aid in post-conflict reconstruction.

\section{Conclusion}

The conflict in the former SFRY and the subsequent international war between the Republic of Croatia and Serbia and Montenegro, together with ethnic conflicts in Bosnia, was the biggest conflict of the post-Cold War period in Europe. The influx of refugees and the concomitant humanitarian crisis endangered Europe. War stopped the functioning of economies in transition to the liberal market and curtailed European and Japanese involvement in the region. Until now, researchers have only looked at the influence of the EU, UN, NATO, US and Western European countries in the Yugoslav crisis, but the Asian part of the ideological West - Japan - has been overlooked. These ideologically close countries and international institutions continued their relations, upholding liberal values in the post-Cold War period in order to stabilize the new world order, created through the emergence of new sovereign countries after the fall of communism. Therefore, this article sheds new light on the Asian aspect of the West, the role of Japan, during the end of the war in former SFRY.

Japan regarded the Yugoslav crisis as a result of deep regional and historical European problems. Because the Yugoslav crisis was acknowledged by the international community as a global task of building a new international order in the post-Cold War period, Japan joined in efforts to resolve the conflict and humanitarian crisis. This way, Japan was able to restart its relations with newly democratized Central and Eastern

${ }_{34}$ Gaikoseisho (January 1 - December 31, 1997, 1997). Tokyo: Gaimusho.

35 Gaikoseisho (January 1 - December 31, 1998, 1998). Tokyo: Gaimusho. 
Europe and improve its economic and political relations with Western Europe and the EU.

First, Japan pursued a foreign policy of maintaining peaceful cooperation, especially with the UN and the Contact Group. In April 1995 Foreign Minister Kono was the first official to visit the former SFRY after war broke out. Foreign Minister Kono met with Croatian officials in Zagreb and with Serbian and Macedonian officials in Budapest, where he clearly presented Japanese thinking that it was not possible to resolve the conflict through the use of military power. Japan's position advocated negotiations in the international arena and humanitarian aid. Summoning leading figures from Croatia, Serbia and Macedonia for bilateral talks in Croatia and Hungary, renewed expectations of Japan as peace mediator.

Consequently, Japan enacted an active foreign policy, especially in Croatia and Bosnia. Japan provided extensive aid, however, there was a problem with its recognition by ordinary Croatian, Muslims and Serbian citizens. Therefore, in order to show a "visible face of aid" MOFA collaborated with UNHCR on a project building a refugee shelter in Croatia in November 1995. This project was promoted by Foreign Minister Kono during his visit to Croatia. It was the practical part of Japanese efforts to expand and strengthen humanitarian, restoration and reconstruction aid.

Lastly, preventive diplomacy for conflict containment held a special place in the Japanese approach towards Bosnia and the surrounding countries. In order to contain hostilities, Japan provided generous aid to Albania and Macedonia, participated in OSCE missions in Vojvodina, Kosovo and Macedonia. The main objective of those missions was the protection of minorities, providing election observers, and strengthening of the economic base to contribute to regional stabilization. This way, Japan as a G7 and Peace Implementation Committee member played a substantial role in the civil aspects of peace implementation and in the economic reconstruction efforts of the international community in the former Yugoslavia.

Yugoslav case served as a blueprint for Japanese diplomacy in cases of ethnic conflict. In order to remain in good relations and advance to friendly relations with states in conflict, such as the case of former Yugoslavia, Japanese diplomacy acted impartially in international society and did not take sides in what had become international war. That way, Japan preserved prior and secured future economic interests in region. Japan used multilateral frameworks such as the UN and OSCE to extend its aid in civilian sector. This way, Japan avoided negative criticism from Asian neighbours by using the soft and smart power tools in its possession, and played its role in globalized world commensurable to its economic power.

\section{Bibliography}

Akashi, Yasushi. An Agenda for Hope: The UN in a New Era, Tokyo: The Simul Press, Inc., 1993.

Akashi, Yasushi. "The Use of Force in a United Nations Peace-Keeping Operation: Lessons Learnt from the Safe Areas Mandate.” Fordham International Law Journal 19, no. 2, 16, 
Akashi, Yasushi, and Okamoto, Y. "Gurobarizeshon wa Nihonjin no PKO Ishiki ni mo (Globalisation in the Japanese PKO Consciousness)", Gaiko Forum, No. 119 (June 1998): 8287.

Bacon, Paul, Mayer, Hartmut, Nakamura, Hidetoshi . The European Union and Japan: A New Chapter in Civilian Power Cooperation? England: Ashgate Publishing Limited, 2015.

Beširević, Nataša. Vanjska politika Europske Unije i Zapadni Balkan (Foreign Policy of the European Union and Western Balkans), Zagreb: Fakultet političkih znanosti, 2013.

Bethlehem, Daniel, and Weller, Marc. The Yugoslav Crisis in International Law, Part of Cambridge International Documents Series. Cambridge University Press, 1997.

Blockmans, Steven. Though Love: The European Union's Relations with the Western Balkans. The Hague: T.M.C. Asser Press, 2007.

Boutros-Ghali, Boutros. An Agenda for Peace. New York: United Nations, 1995. Gilson, Julie. Japan and the European Union: A Partnership for the Twenty-First Century? Great Britain: Macmillan Press Ltd. 2000.

Gilson, Julie. "Japan in Kosovo: lessons in the politics of 'complex engagement'." Japan Forum, 12:1 (2000): 65-75.

Glaurdić, Josip. The Hour of Europe: Western Powers and the Breakup of Yugoslavia, Yale University, 2011.

Glišić, Nenad. "Relations between the Republic of Serbia and Japan.” Interview with Marcela Perić. Embassy of Republic of Serbia in Japan: February 27, 2019.

Grubiša, Damir, Beširević, Nataša, and Špehar, Hrvoje. Politički sustav Europske Unije $i$ europeizacija hrvatske politike (Political System of the European Union and Europeanization of Croatian Politics). Zagreb: Fakultet političkih znanosti, 2012.

Hook, Glen D. et al. Japan's International Relations: Third Edition. The University of Sheffield, 2011.

Hosoya, Yuichi. "The evolution of the EU-Japan relationship: towards a 'normative partnership?"' Japan Forum, 24:3 (2012): 317-337.

Hrastić, Dražen. „Relations between the Republic of Croatia and Japan.” Interview with Marcela Perić. Embassy of Republic of Croatia in Japan: February 28, 2019.

Jabareen, Yosef. “Conceptualizing 'Post-Conflict Reconstruction' and 'Ongoing Conflict Reconstruction' of Failed States.” International Journal of Politics Culture and Society 26 (2013): 107-125. 
Keck, Jörn. "Chapter 4: 1990-1995 The Politics of Cooperation.” In: EU-Japan Relations, 1970-2012 From confrontation to global partnership by Keck, Jörn, Vanoverbeke, Dimitri, and Waldenberger, Franz, 111-154. London and New York: Routledge, 2013.

Matsumoto, Hiroshi. "Kuroachia Nanmin Sheruta Kensetsu (Construction of Refugee Shelter in Croatia)." Gaiko Forum no. 103 (March 1997): 58-59.

Miškulin, Ivica. "Icecream and Sun - The European Community Monitoring Mission and Croatia, 1991-1995." Review of Croatian History, 2010.

Miškulin, Ivica. “An Avoidable Failure: Peacekeeping in Croatia, 1991-1995.” Review of Croatian History 7 no.1 (2011): 37-77.

MOFA. Gaikoseisho [Diplomatic Bluebook]. Tokyo: Gaimusho (August 1989 - July 1990, 1989).

MOFA. Gaikoseisho [Diplomatic Bluebook]. Tokyo: Gaimusho. (January 1 - December 31, 1995, 1995).

MOFA. Gaikoseisho [Diplomatic Bluebook]. Tokyo: Gaimusho. (January 1 - December 31, 1996, 1996).

MOFA. Gaikoseisho [Diplomatic Bluebook]. Tokyo: Gaimusho. (January 1 - December 31, 1997, 1997).

MOFA. Gaikoseisho [Diplomatic Bluebook]. Tokyo: Gaimusho. (January 1 - December 31, 1998, 1998).

MOFA. Gaikoseisho [Diplomatic Bluebook]. Tokyo: Gaimusho. (January 1 - December 31, 1999, 1999).

MOFA. "Statement by Prime Minister Tomiichi Murayama 'On the occasion of the 50th anniversary of the war's end'". October 28, 2018. Retrieved from https://www.mofa.go.jp/announce/press/pm/murayama/9508.html MOFA. “Kosovo Situation: Japan's Personnel Contribution.” August 5, 1999. Retrieved from https://www.mofa.go.jp/announce/announce/1999/8/805.html

MOFA. Foreign Policy Speech by Foreign Minister Watanabe to the 126th Session of the National Diet, January 22, 1993.

MOFA. "Statement by Prime Minister Tomiichi Murayama 'On the occasion of the 50th anniversary of the war's end"'. October 28, 2018. Retrieved from

https://www.mofa.go.jp/announce/press/pm/murayama/9508.html

MOFA. "Foreign Policy Speech by Foreign Minister Watanabe to the 126th Session of the National Diet.” January 22, 1993. 
MOFA. “Kosovo Situation: Japan's Personnel Contribution.” August 5, 1999. Retrieved from https://www.mofa.go.jp/announce/announce/1999/8/805.html

Mykal, Olena. The EU-Japan Security Dialogue: Invisible but Comprehensive, Amsterdam: Amsterdam University Press, 2011.

Nazor, Ante. "Pregled djelovanja hrvatskih snaga u Hrvatskoj i Bosni i Hercegovini 1990-ih (An Overview of the Actions of Croatian Military Forces in Croatia and Bosnia and Herzegovina). “In: Tuđmanov arhiv (Tuđman's Archive), edited by Miroslav Tuđman, Book IV. Zagreb: Hrvatska sveučilišna naklada, Hrvatski institut za povijest, 2015.

Owada, Hisashi. Sankaku kara Souzou he - Nihon Gaiko no Mezasu mono (From the Triangle to the Structure - The Goals of Japanese Foreign Policy). Tokyo: Toshishuppann Kaisha, 1995.

Savill, Annika. "20 killed in shell attack on Gorazde hospital: Continuing threats of Nato air strikes have failed to curb the Serbian offensive against the Muslims.” Independent. April 21, 1994.

Smith, Karen E. The Making of EU Foreign Policy: The Case of Eastern Europe, Palgrave Macmillan, 2004.

Sudetic, Chuck. "Serbs Press Attack on Muslims in Gorazde.” New York Times, April 4, 1994.

Tuđman, Miroslav. Tuđmanov arhiv: Korespondencija predsjednika Republike Hrvatske dr. Franje Tudmana od 1990. do 1999. godine (Tudman's Archive: Correspondency of the President of Republic of Croatia Dr. Franjo Tuđman from 1990 to 1990), Books IV - VI, Zagreb: Hrvatska sveučilišna naklada, Hrvatski institut za povijest, 2015.

Tsukimura, Taro. Yugo Naisen: Seiji Rida to Minzokushugi (Ethnopolitical Leaders in Internal Wars in Croatia, and Bosnia and Herzegovina). University of Tokyo Press, 2006. Tsuruoka, Michito.'“Expectations Deficit' in EU-Japan Relations: Why the Relationship Cannot Flourish.“ Current Politics and Economics of Asia 17, no. 1 (2008): 107-126., Tsuruoka, Michito. “The Development of Political and Security Relations between Japan and Europe after World War II. “, PhD diss., Department of War Studies, King's College London, 2012.

Tsuruoka, Michito. "NATO and Japan as Multifaceted Partners." NATO Defense College, Research Division, No. 91, Rome, 2013.

Unknown author. "Profile: Bureaucrat at large in the Balkans: Yasushi, Akashi, almost painfully diplomatic UN envoy.” Independent. April 29, 1994. 
ANZJES 11(2)

Yagi, Takeshi. "Nihon no Yakuwari wa Nanika (What is Japan's Role)", Gaiko Forum, no. 92 (May 1996): 18-24. 